Geo-Marine Letters (1986) 6:165-172

Geo-Mlarine

Ietters

a) I06 Springer-Verlag New York Ins.

\title{
Accumulation of Biogenic Silica and Opal Dissolution in Upper Quaternary Skagerrak Sediments
}

\author{
Gerhard Bohrmann \\ Geologisch-Paläontologisches Institut und Museum der CAU, Olshausenstraße 40/60, D-2300 Kiel, Federal \\ Republic of Germany
}

\begin{abstract}
In a core from the outer Skagerrak, the content of biogenic opal is higher in Late Pleistocene (Younger Dryas) than in Holocene deposits. In terms of opal accumulation, rates are $1 \mathrm{~g} / \mathrm{cm}^{2} /$ 1,000 y during the Holocene and five to ten times larger during the Younger Dryas. Intensive dissolution has greatly reduced the Holocene opal content and does not allow calculation of paleoproductivity. The intensity of opal dissolution is reflected by dissolution stages of both the diatom Paralia sulcata and sponge spicules. The intensity of dissolution is negatively correlated to the sedimentation rate and appears to be controlled by silica-undersaturated environment on the sea floor and the uppermost sediment layer.
\end{abstract}

\section{Introduction}

Within the scope of the Oslofjord-Skagerrak-Project (OSKAP), the sediment core GIK (Geol. Inst. Kiel) 15530-4 from Skagerrak was investigated intensively at the Department of Geology at the University of Oslo, Norway with participation of numerous other institutions [1]. The $10.74 \mathrm{~m}$ long core came from the Southern flank of the Norwegian Channel (Fig. 1) at a water depth of $325 \mathrm{~m}$ [2]. It shows a continuous sediment section (Fig. 2) representing the entire Holocene and the upper parts of the Younger Dryas (YD) back to approximately 11,000 y B.P. 13]. Rapid changes of terrigenous input and biogenic component fluxes are produced by the distinct climatic change and related changes in the hydrography at the Holocene/Pleistocene boundary (Preboreal/Younger Dryas; [1]).

Controversial interpretations exist on the paleoproductivity of the water masses during the time rep- resented by this sediment core. On the basis of distribution of organic carbon, Wassmann [4] gave these estimates for paleoproductivity: low content of organic carbon $\left(30\right.$ to $50 \mathrm{~g} / \mathrm{m}^{2} / \mathrm{y}$ ) in the Younger Dryas (YD) and Preboreal (PB), average content ( 80 to 90 $\left.\mathrm{g} / \mathrm{m}^{2} / \mathrm{y}\right)$ in the Atlantic (A) and Boreal (B), and highest content (about $100 \mathrm{~g} / \mathrm{m}^{2} / \mathrm{y}$ ) in the Subboreal (SB) and Subatlantic (SA). These estimates are not in agreement with the interpretation of Thiede [5] who postulated a highly productive stage for the Late Pleistocene on the basis of higher accumulation rates of diatoms and benthic foraminifers.

This study provides additional evidence of paleoproductivity based on biogenic silica accumulation rates. Generally, the opal content of pelagic and hemipelagic sediments is the result of combined influences of biogenic silica production, dilution by terrigenous debris, and chemical opal dissolution. In this study, both the opal contents of bulk sediment and opal accumulation rates were determined to eliminate dilution by non-opal components. As there is no method to quantify biogenic silica dissolution, qualitative descriptions of dissolution intensities of various opal skeletons were carried out to characterize the opal preservation stage of the sediment.

\section{Methods}

Two different methods were used to quantify the biogenic opal content because of the low values expected. At first, the sediment was treated with hydrogen peroxide and acetic acid to remove both organic matter and carbonate. The clay fraction $(<2 \mu \mathrm{m})$ was separated by the Atterberg method [6]. A heavy-liq- 


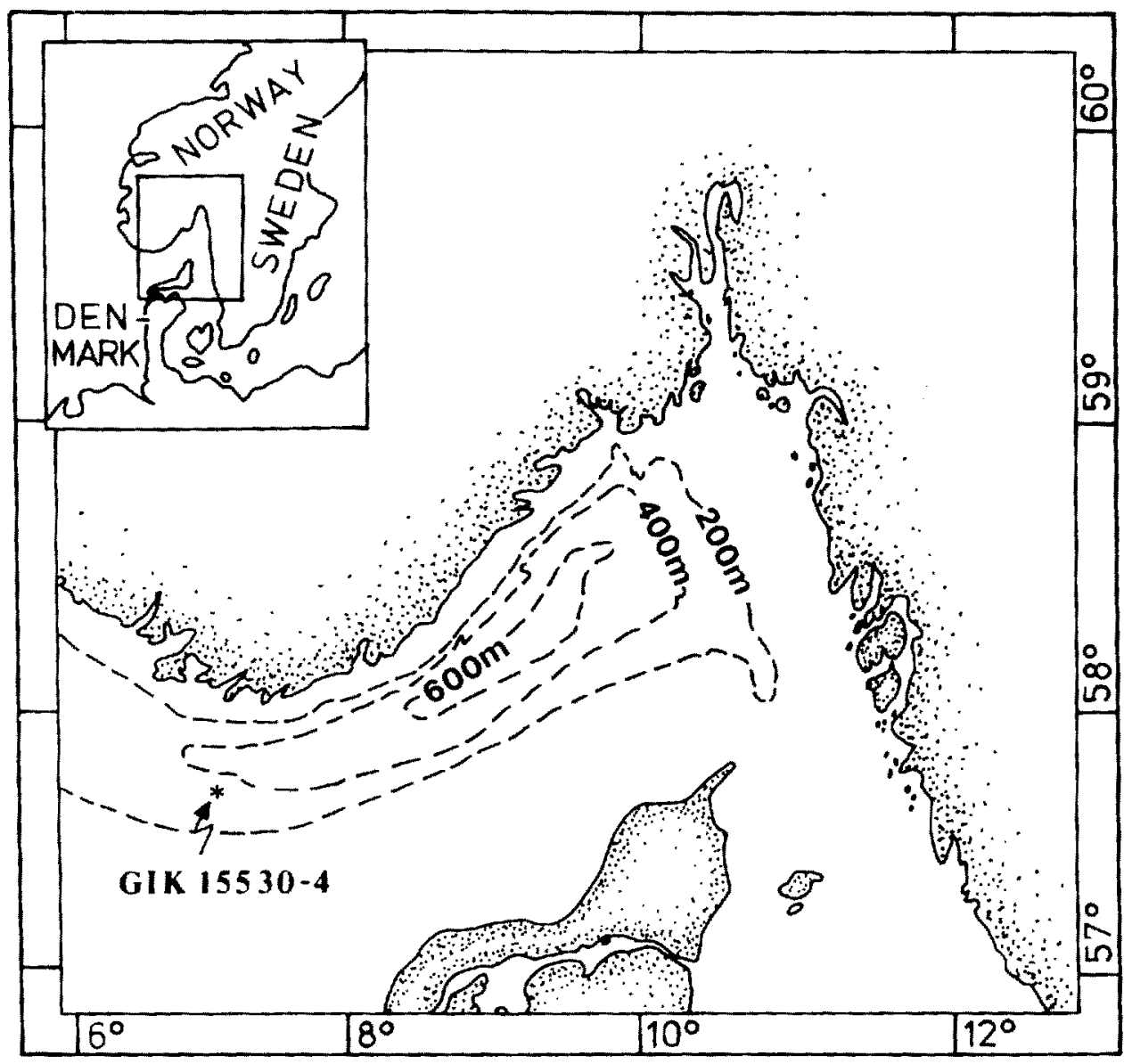

Figure 1. Position of the investigated sediment core GIK $15530-4$ at $57^{\circ} 40.0^{\prime} \mathrm{N} \cdot 7^{\circ} 5.5^{\prime} \mathrm{E}$ : sampled 8 November 1980 during a $F / S$ Poseidon cruise. uid solution of bromoform and dimethylformamid (density $=2.25 \mathrm{~g} / \mathrm{cm}^{3}$ ) was added to the washed and freeze-dried $>2 \mu \mathrm{m}$ fraction. After density separation by centrifuge, the heavy fraction was frozen with liquid nitrogen to allow separation of the lighter opal fraction. Both light and heavy fractions were washed several times with alcohol to recover the heavy-liquid solution. After drying the fractions were weighted.

Next, a detailed counting method [7] was applied. The abundances of diatoms and sponge spicules were analyzed microscopically by smear slide counts in six subfractions of the carbonate-free silt fraction. After the gravity separation, 11 samples from different core depths were prepared to study features of opal dissolution with the scanning electron microscope. Standard dissolution stages for Paralia sulcata and sponge spicules were established and the degrec of dissolution for each sample was estimated by a semiquantitative calculation of dissolution stages.

\section{Biogenic Silica in Core 15530-4: Concentrations, Accumulation Rates, and Composition}

Figure 3 displays the opal contents analyzed by the two different methods described previously. Although the absolute content differs somewhat, the curves are generally coincident. Opal minima are found in the Subboreal, Atlantic, and Boreal (0.1 to 0.3\%); with maxima confined to the Preboreal $(0.8 \%)$ and Younger Dryas $(1.5 \%)$. The accumulation rates of biogenic silica (Fig. 3) were determined from the opal content (wt.\%) and the bulk sediment accumulation rates as established by Thiede [5]. Opal accumulation is generally low $\left(<1 \mathrm{~g} / \mathrm{cm}^{2} / 1,000 \mathrm{y}\right)$, but increases in the Preboreal and reaches a maximum at the time of the latest Glacial (late Younger Dryas) at approximately 10,400 y B.P. (12 to $16 \mathrm{~g} / \mathrm{cm}^{2} / 1,000 \mathrm{y}$ ). Using interpolations of linear sedimentation rates, the time span 10,600 to 10,800 y B.P. (Fig. 3) is associated with lower opal accumulation of 4 to $6 \mathrm{~g} / \mathrm{cm}^{2} / 1,000 \mathrm{y}$.

Figure 4 displays the variations in content of diatom valves and sponge spicules which are the two major opal components from the sediment core. Diatoms are more abundant in the Preboreal and Younger Dryas than in all other chronozones. Higher amounts of sponge spicules are recorded in the Subatlantic, Subboreal, and Boreal. The third column in Figure 4 displays the ratios of sponge spicules to diatoms. In general, the ratios are higher in the upper $6 \mathrm{~m}$ of the core than in the lower part. 


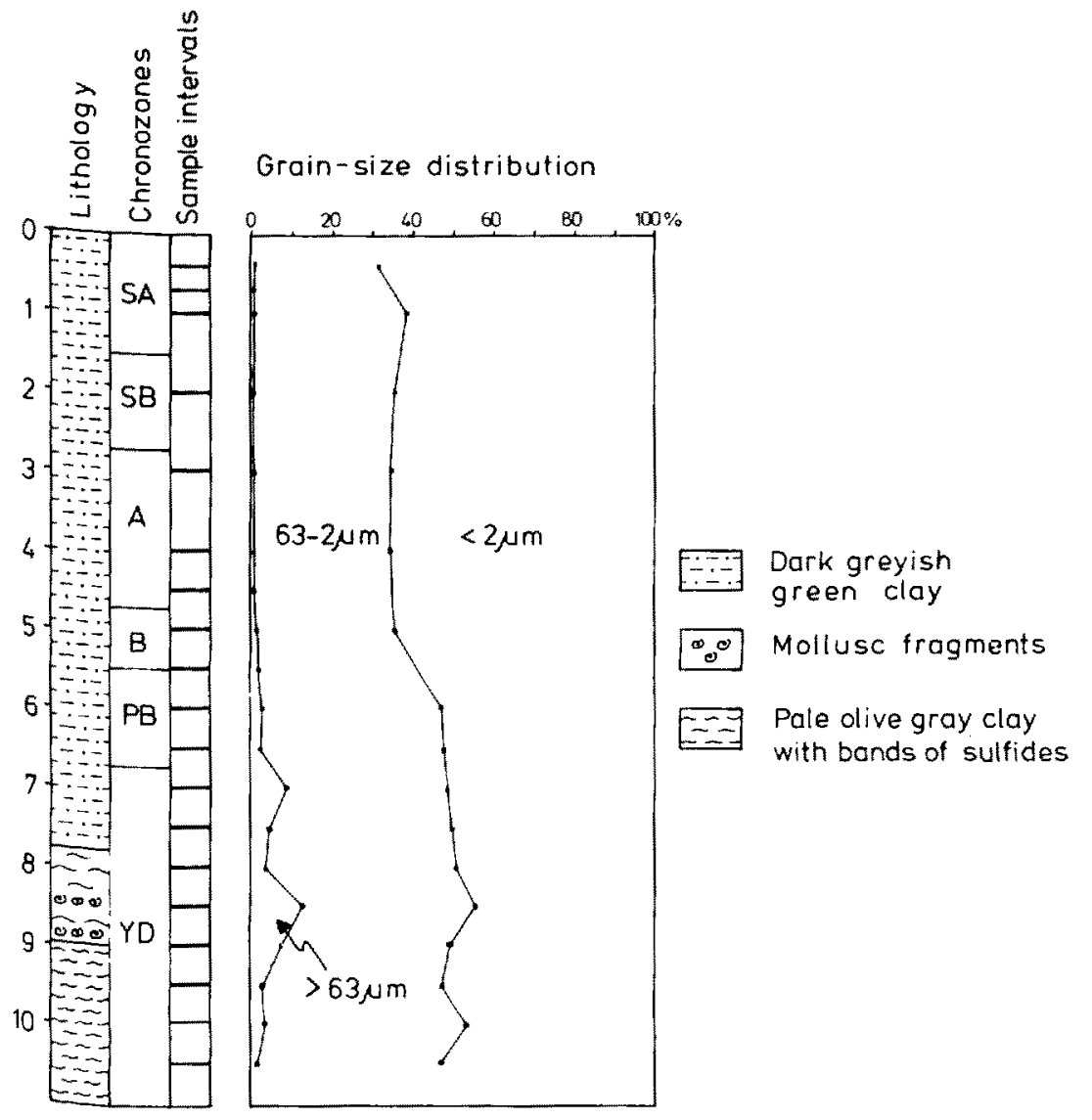

Figure 2. Lithostratigraphy and grain-size distribution of the core GIK 15530-4. Chronozones after Stabell and Thiede (1); $\mathrm{SA}=$ Subatlantic, $\mathrm{SB}=$ Subborcal, $\mathrm{A}=$ Atlantic, $\mathrm{B}=$ Boreal, $\mathrm{PB}=$ Prcboreal. $\mathrm{YD}$ $=$ Younger Dryas.

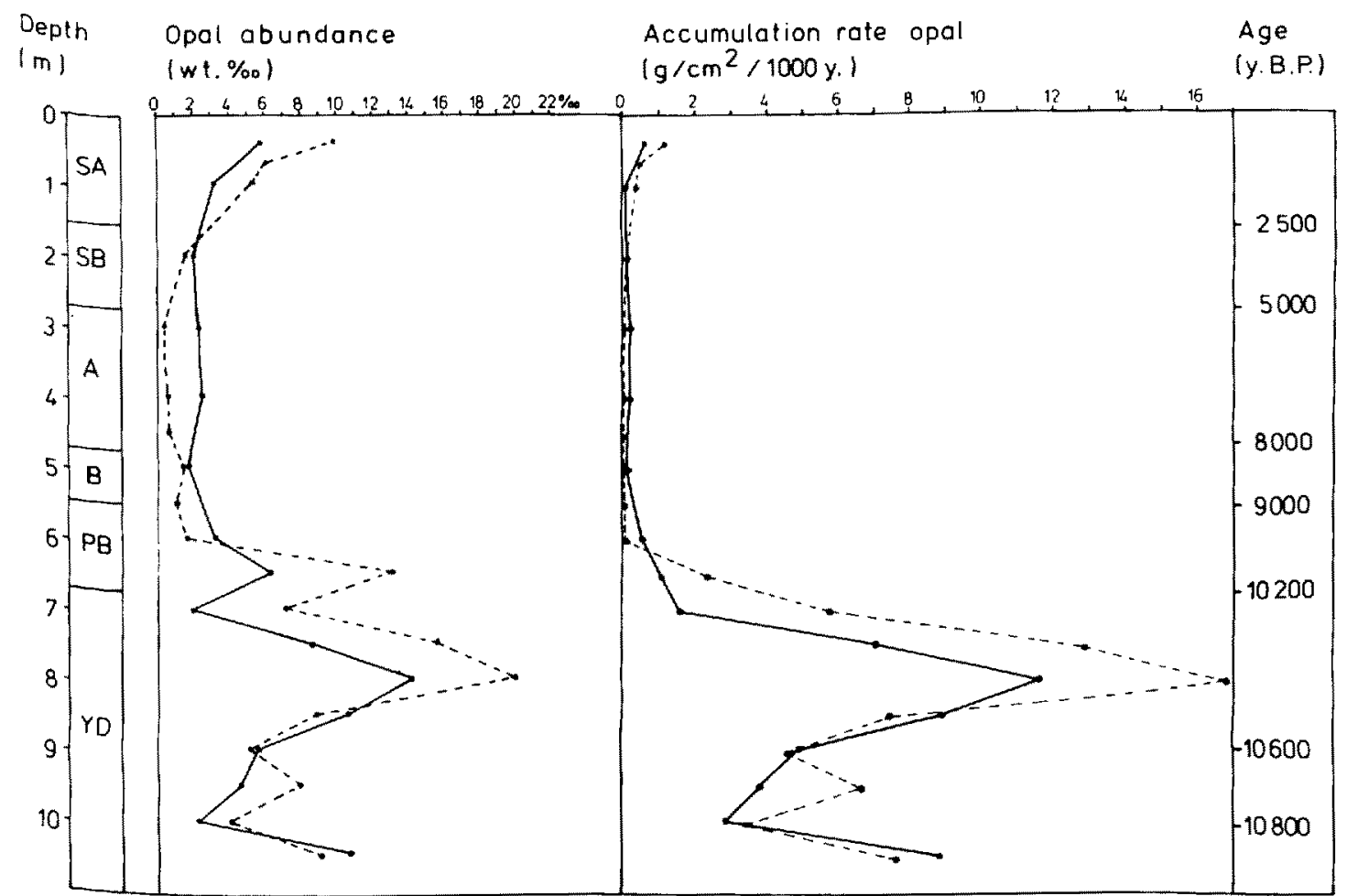

Figure 3. Opal contents and opal accumulation rates calculated from bulk accumulation rates [5]. Dashed line $=$ opal contents using the determination method of Koopmann [7]: solid line = opal contents in weight percentages after separation in aravity solution. 


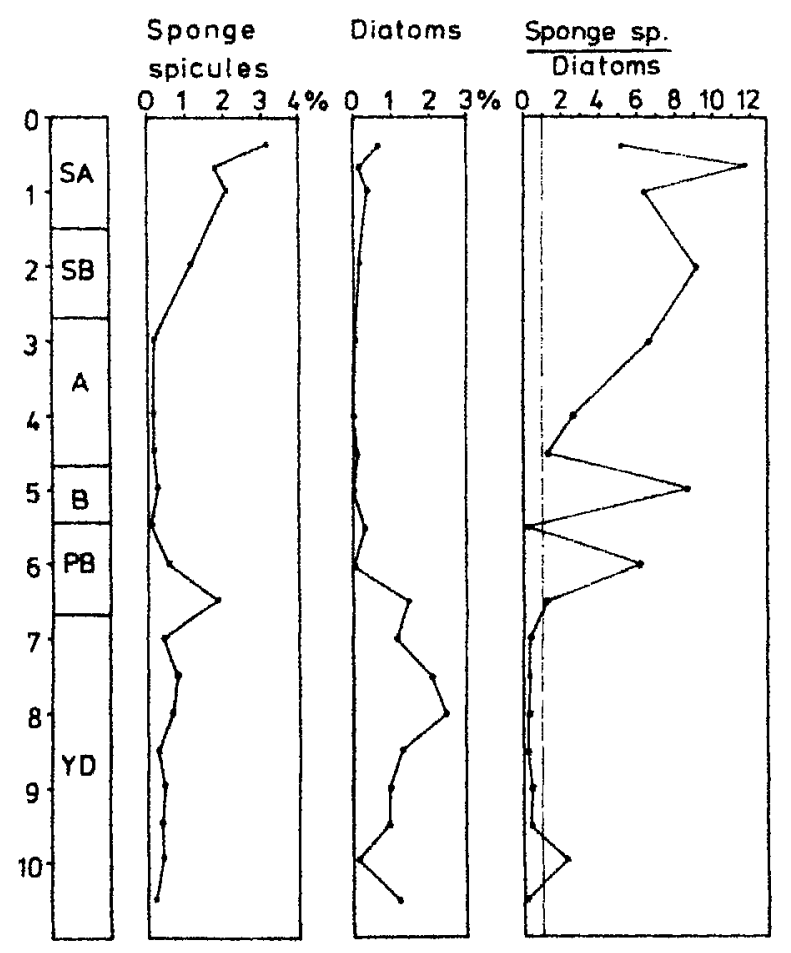

Figure 4. Percentage of sponge spicules and diatoms in the carbomate-frec fraction 2 to $63 \mu \mathrm{m}$.

\section{Features of Opal Dissolution in Core GIK 15530-4}

Opal dissolution in core GIK 15530-4 was already mentioned by other investigators. On the busis of radiolarians, Björklund $|8|$ describes the interval 3.0 to $6.0 \mathrm{~m}$ depth generally as a level of poor opal preservation. Stabell 191 records an interval barren of diatom frustules from 0.55 to $5.25 \mathrm{~m}$ core depth and assumes an intensive dissolution within this part of the corc. The opal skeletal remains have a variable dissolution resistance $(10,1)$, a result of differences in structure, chemical composition $\mid 12\}$, geometrical construction, and specific surface area constitution. Consequently the intensity of opal dissolution should he estimated on the basis of one group of organisms or even better on the basis of one single species.

\section{Dissolution Stages of the Diatom Paralia Sulcata}

The intensity of dissolution was studied on the rather robust diatom Paralia sulcata (Ehrenberg), which is found in nearly all core levels 191 . It possesses a relatively short cylindric theca with a flat discus showing characteristic radial ribs and a narrow corded basal ring (Fig. 5A). Schrader $|10|$ had made some dissolution experiments with the diatom $P$. sulcata, using varying concentrations of $\mathrm{NaOH}$ solutions. His results indicate dissolution features similar to the following four stages of increasing dissolution which were defined on samples from 11 core intervals:

Stage $I=$ No dissolution: The valves reveal very smouth surfaces. Absence of some skeleton parts, c.g., some peripheral appendices, may be due to mechanical breakage during the analytical procedure (Fig. 5A).

Stage $2=$ Initial to progressive dissolution: Stage 2 shows a series of substages of dissolution, which are summarized hecause of delimination problems. Initially, dissolution results in a fine-granulated surface which in turn is transformed into a coarse granulated surface relief. The roughness of surface first is developed in the teeth-bordered marginal area including the radial ribs or grooves. During progressive stage of dissolution, the massive hat central discus part still retains a smooth surface. Further dissolution enlarges the pores on the flanking margin and on the corded ring (Fig. 5B). Simultaneously, the radial grooves become deeper and the central discus area shows a fine porous surface.

Stage 3 = Strong dissolution: During more extensive dissolution, the teeth-like peripheral cell links disappear and the originally fine pores become larger and irregular so that the whole margin of the valve is easily broken (Fig. 5C).

Stage $4=$ Very strong dissolution: During final dissolution, the area of radial ribs and grooves of $P$. sitlcula disappears and only the central hat part of the valve is preserved. The remains of the radial elements are still rarely found and in most cases there are only unidentifiable corroded opal plates, representing the formerly massive central part of the valve (Fig. 5D). The opal plates are considered to be remains of $P$. sulcata because there are no other opal particles with such a massive central flat area.

\section{Dissolution Stages of Sponge Spicules}

An additional parameter of dissolution intensity is supplied by preservation features of sponge spicules. It is practical to distinguish the three following steps of dissolution:

Figure 5. Scituning clectron microscope pictures of opal skeleton remains from corc GIK 15530 -4. Scale bar $=5 \mu m$. $A=$ Diatom Parulia sulrata: Dissolution stage I (Sample 12; $7.0 \mathrm{~m}$ core depth). B :: P. shlcala: Dissolution stuge 2 (Sample 3; $1.0 \mathrm{~m}$ core depth). $C=P$. sulcena: Dissolution stage 3 (Sample $4 ; 2.0 \mathrm{~m}$ core depth). D - Remains of P. sulcala: Dissolution stage 4 (Simple $4: 2.0$ in core depth). $\mathrm{f}=$ Sponge spicule: Dissolution stage 1 (Simple $18 ; 9.0 \mathrm{~m}$ core depth). F = Sponge spicules: Dissolution stage 3 (Sample $4: 2.0$ in corc depth). 

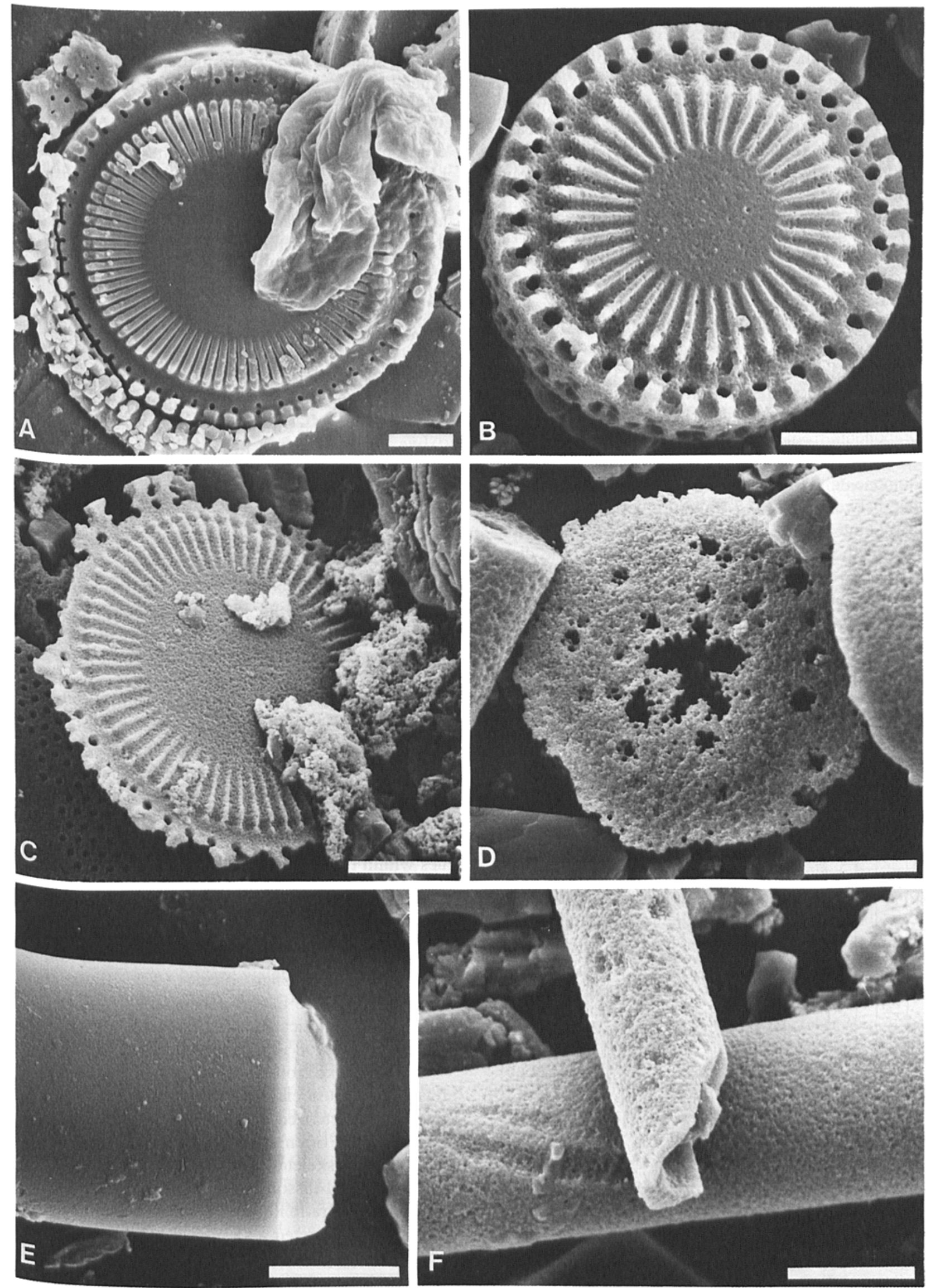
Stage $I=$ The sponge spicules have smooth- to only very fine-granulated surfaces (Fig. 5E).

Stage $2=$ The outer face of sponge spicules reveals fine- to coarse-granulated structure.

Stage 3 = The wall thickness is reduced during progressive corrosion, so that a slight stress could easily produce some fragments. Additionally, scattered corrosion pits (Fig. 5F) are developed on the very rough surfaces.

\section{Major Pattern of Opal Dissolution in Core GIK $15530-4$}

Since $P$. sulcata and sponge spicules are widely distributed components in almost the entire sediment core, the intensity of opal dissolution can be classified on the basis of their dissolution features. Figure 6 displays the variations in dissolution stages of the two components from 11 depth intervals which can be directly correlated. The best preservation of both opal components are recorded in the lowermost four samples (between 10.0 to $7.0 \mathrm{~m}$ core depth) representing the Younger Dryas. According to the corrosion structures of the opal particles from this level, the dissolution was too weak to show some corrosion effects. The maximum chemical dissolution is found between 5.0 to $2.0 \mathrm{~m}$ core depth in the Subboreal, Atlantic,

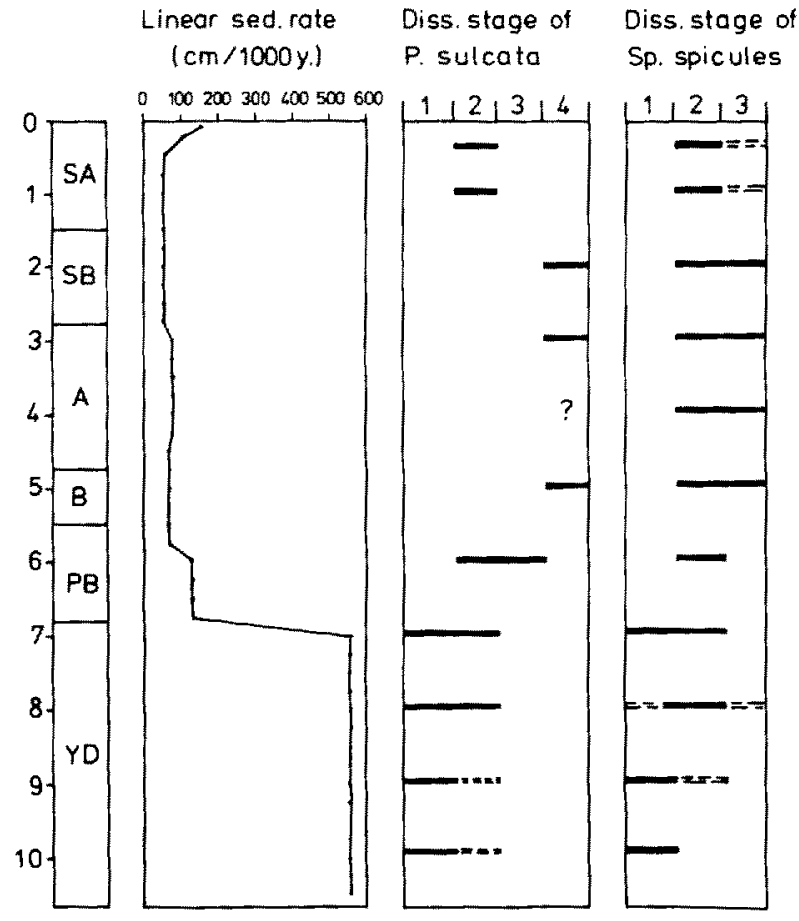

Figure 6. Preservation patterns of biogenic silica as reflected by the dominant dissolution stages of the diatom Paralia sulcata and sponge spicules. Linear sedimentation rates from Thicde $[5]$. and Boreal where $P$. sulcata reaches the dissolution stage 4 coinciding with the dissolution maxima of sponge spicules. Linear sedimentation rates (LSR) of Thiede $[5]$ are also plotted in Figure 6. The best opal preservation coincides with the highest sedimentation rate of $550 \mathrm{~cm} / 1,000 \mathrm{y}$ in the Younger Dryas. Preservation of biogenic silica diminishes with decreasing LSR in the Preboreal and reveals a minimum in the Boreal, Atlantic, and Subboreal. In the Subatlantic a higher degree of opal preservation again coincides with a small increase of the LSR.

\section{Discussion and Interpretations of the Results}

In general, only a small part of the biogenic opal skeletons mainly produced in the surface water is incorporated into the sediment record. A great portion of the amorphous mineralogically unstable opal is dissolved within the silica-undersaturated marine environment $[13-15]$. The dissolution of biogenic silica may occur: a) in the water column during settling, b) on the sea floor at the sediment-water interface, c) within the sediment under the influence of silica-undersaturated pore water. Lisitzin $[16,17]$ postulates that the largest part of biogenic silica produced in surface water again is reduced by dissolution within the uppermost meters of the sea water column. However. based on sediment-trap data Broecker and Peng |18| found that only a little silica dissolution occurs during settling of the particles through the water column. They inferred that most of the opal dissolution occurs on the sea floor. In addition, new observations on the vertical flux of sinking fecal pellets and phytoplankton aggregates [19-21] suggest that biogenic silica may be rapidly transported to the sea floor without major dissolution. In this case intensive dissolution occurs first at the sediment-water interface and then continucs within the uppermost centimeters of the sediment under the influence of silica-undersaturated pore water.

In the marine environment, different groups of siliceous skeletons show a progressive dissolution: first silicoflagellates disappear, then diatoms and radiolarians, and lastly sponge spicules [10]. However, the variable resistance of different opal skeletons to dissolution is complicated in particular cases and is not clearly understood in all its specific aspects [22].

The opal skeletons investigated in this report are relatively robust elements. Sponge spicules are especially characterized by a high solution resistance and, therefore, are often concentrated in dissolution residues of opal skeleton assemblages [23]. Because of the differential dissolution effect, a high sponge spicule to diatom ratio in the Holocene core portion (Fig. 4) can be interpreted as a high degree of opal dissolution. Correspondingly, the generally lower ratio in 
the Pleistocene succession seems to be related to a lower intensity of dissolution. This simplified interpretation of the variation of the sponge spicule/diatom ratio, however, may be complicated by redeposition of biogenic silica components. In particular, sponge spicules which are produced in higher amounts in sublittoral areas can be transported easily as allochthonous debris to deeper areas of sedimentation. The sponge spicule maximum in the Preboreal $(6.5 \mathrm{~m}$ core depth) may probably be one of these redeposition effects. This is in agreement with the assumption of Stabell [9] who suggests that the majority of diatoms from this interval are allochthonous valves brought in from the shallow areas as a result of a change in the circulation pattern. Higher content of sponge spicules in Subboreal and Subatlantic could also indicate stronger redeposition processes. The strong dissolution of $P$. sulcata, and resistant sponge spicules obServed in the Holocene section of the core is due to dissolution on the former to recent sea floor and/or in the uppermost sediment layer. In this layer, a strong gradient of dissolved silica and a more or less continuous flux to the bottom water is developed [22]. This seems to be confirmed by the observation that the linear sedimentation rate is negatively correlated to the opal dissolution intensities (Fig. 6). In the Holocene, during a time with smaller LSR, the opal components slowly pass the layer of silica-undersaturation, leaving enough time for intensive dissolution.

In the Pleistocene section, where the LSR are four to seven times higher, the opal particles on burial pass through this layer more rapidly and are, therefore, less affected by dissolution. The strong shifting of the LSR seems to be the primary controlling factor for opal preservation in the sediments of core GIK 15530-4. Other important factors for post-burial opal preservation, controlling the silica concentration of pore water and the degree of undersaturation, are discussed by Schink and Guinasso [22] and include: input of biogenic silica, bioturbation rates, dissolution rates of different opal components, dissolved silica concentration of overlying bottom water, porosity, diffusion, adsorption coefficients of the sediment, and reaction rates of other solid phases.

In this core, the bioturbation rate could have also played a significant role. X-ray radiographs investigated by Werner [24] show more layered structures in the glacial section, whereas the Holocene succession shows biogenic structures, e.g., feeding spreiten, which indicate a stronger mixing of sedimentary components by bioturbation. According to Schink and Others [25], an increased bioturbation rate carries reactive opal matcrial downward and leads to an increase in the asymptotic silica concentration of pore water which was reached when going deeper. Higher concentrations of dissolved silica cause a steeper gradient and a higher flux of dissolved silica from pore water to marine bottom water. The result is a stronger dissolution of opal components. According to this model [25], the higher amount of bioturbation in Holocene could have intensified the opal dissolution.

When interpreting changes of opal accumulation rates in terms of changes of paleoproductivity, the possibility and importance of changes in opal dissolution has to be considered. Between 2 to $4 \mathrm{~m}$ core depth, the diatom $P$. sulcata was intensively corroded to unidentifiable opal plates (dissolution stage 4) and it could be assumed that some of these individuals, and other opal skeletons which are slightly soluble, were completely dissolved. In the present sediment core, it is impossible to estimate how much opal was lost by dissolution. Therefore, the variation of the opal accumulation rates during the Holocene cannot be interpreted as a signal of productivity from previous water masses. Only in the Pleistocene succession during a time of an unchanged low opal dissolution, an increase of opal accumulation approximately at 10,400 y B.P. (Fig. 3) after a time of decreased opal accumulation between 10,800 to 10,600 y B.P., can be considered as indication of more productive water masses.

\section{Conclusions}

1) The opal contents and the opal accumulation rates of sediment core GIK 15530-4 were higher in the latest Pleistocene than during the Holocene. 2) During the Holocene, biogenic opal was strongly affected by intensive dissolution, so that estimations of the primary production on the basis of opal accumulation rates are therefore unreliable. 3) The observed opal dissolution most probably was due to corrosion in contact with the silica-undersaturated water on the sea floor and the uppermost sediment layer. It was probably mainly controlled by strong shifts in the sedimentation rates.

\section{Acknowledgments}

I thank J. Thiede, G. Wefer, R. Henrich. H. Zimmerman, F. Werner, G. Fischer, R. Merkel, P. Hempel. and $S$. Hempel for eritical remarks and reviewing the manuscript. A. Abelmann. B. Stabell. and $W$. Ehrmann have made helpful comments. I also thank R. Reimann for operating the SEM. Finineial support was provided by the "Deutsehe Forschungsgemeinschaft."

\section{References}

1. Stabell B. Thicde J (1985) The physiographic evolution of the Skagerrak during the past 15,000 years: Paleobathymetry and palcogeography. Norsk Geologisk Tidsskrift 65:19-22 
2. Stabell B. Werner F, Thicde J (1985) Late Quaternary and modem sediments of the Skagerrak and their depositional en vironment: An introduction. Norsk Geologisk Tidsskrift 65:917

3. Björklund KR, Björnstad $H$, Dale B, Erlenkeuser $H$, Henningsmoen KE, Hocg HI, Johnson K, Manum SB, Mikkelsen N. Nagy J, Peterstad K, Quale G, Rosenquist ITh, Salbu B, Schoenharting G, Stabell B, Thicde I, Throndsen I, Wassmann P, Werner F (1985) Evolution of the Upper Quaternary depositional environment in the Skagerrak: A synthesis. Norsk Geologisk Tidsskrift 65:139-149

4. Wassmann $P$ (1985) Accumulation of organic matter in core GIK 15530-4 and the Upper Quaternary paleo-productivity in the Skagerrak. Norsk Geologisk Tidsskrift 65:131-137

5. Thiede J (1985) Upper Quaternary accumulation rates of marine outer Skagerrak sediments: Core GIK 15530-4. Norsk Geologisk Tidsskrift $65: 125-130$

6. Müller $G$ (1967) Methods in sedimentary petrology. In: $v$. Engelhardt W, Füchtbauer $H$, Müller $G$ (eds) Sedimentary Petrology, Part I. Stuttgart Schweizerbart'sche Verlagsbuchhandlung

7. Koxpmann B (1981) Sedimentation von Saharastaub im subtropischen Nordatlantik während der letzten 25000 lahre. "Meteor"-Forschungsergebnisse, Rcihe C 35:23-59

8. Björklund KR (1985) Upper Weichselian-Holocene radiolarlan stratigraphy in the Skagerrak (NE North Sea). Norsk Geologisk Tidsskrift 65:103-106

9. Stabell B (1985) Diatoms in Upper Quaternary Skagerrak sediments. Norsk Geologisk Tidsskrift 65:91-95

10. Schrader HJ (1972) Kieselsäure-Skelette in Sedimenten des ibero-marokkanischen Kontinentalrandes und angrezender Tiefsee-Ebenen. "Meteor"-Forschungsergebnisse, Reihe C $8: 10-36$

11. Mikkelsen N (1980) Experimental dissolution of Pliocene diatoms. Nova Hedwigia 33:893-911

12. Kamatani A (1971) Physical and chemical characteristics of biogenous silica. Marine Biology 8:84-95

13. Hurd DC (1973) Interactions of biogenic opal, sediment and scawater in the Central Equatorial Pacific. Geochimica Cosmochimica Acta 37:2257-2282
14. Heath GR (1974) Dissolved silica and deep sea sediments. Socicty of Economic Paleontologists and Mineralogists spec. publ. 20:77-93

15. Calvert SE (1974) Deposition and diagenesis of silica in marine sediments. International Association of Sedimentologists spec. publ. 1:273-299

16. Lisitzin AP (1972) Sedimentation in the World Occans. Socicty of Economic Paleontologists and Mincralogists Spec. Publ. 17:1-218

17. Lisitzin AP (1985) The silica cycle during the last ice age. Palacogeography, Palacoclimatology, Palaeoccology 50:241270

18. Broecker WS, Peng TH (1982) Tracers in the sea. Publication Lamont-Doherty Geological Observatory, Palisades, New York

19. Billett DSM, Lampitt RS, Rice AL, Mantoura RFC (1983) Seasonal sedimentation of phytoplankton to the decp-sea benthos. Nature 302:520-522

20. Gersonde $R$, Wefer $G$ (in press) Sedimentation of biogenic siliceous particles in Antarctic waters (Atlantic sector). Marine Micropaleontology

21. Smetacek VS (1985) Role of sinking in diatom life-history cycles: ecological, evolutionary and geological significance. Marine Biology 84:239-251

22. Schink DR, Guinasso NL (1977) Effects of biolurbation on sediment-seawater interaction. Marine Geology 23:133-154

23. Mikkelsen $N$ (1984) Diatoms in the Zaite deep-sea fan and Pleistocene palacoclimatic trends in the Angola Basin and west equatorial Africa. Netherlands Journal Sea Research 17:280292

24. Wemer F (1985) Sedimentary stmetures and the record of trace fossils in Upper Quaternary marine Skagerrak deposits. Norsk Geologisk Tidsskrift 65:65-71

25. Schink DR, Guinasso NL, Fanning KA (1975) Processes affecting the concentration of silica at the sediment-water interface of the Atlantic Ocean. Journal Geophysical Research $80: 3013-3031$

Manuscript received 29 April 1986; revision received 11 July 1986. 